ROCZNIKI PEDAGOGICZNE

Tom 12(48), numer $4-2020$

DOI: https://doi.org/10.18290/rped20124-3

LESZEK WAGA

\title{
EXPERIENCE \\ IN THE PEDAGOGICAL REFLECTION ON FAMILY
}

\section{INTRODUCTION}

Experience is one of the main categories used in the humanities and social sciences, including family pedagogy. However, the term is not unambiguous, and its ambiguity is due to both the variety of colloquial approaches to experience and its numerous scientific concepts which began to arise at the onset of scientific knowledge formation (Waga, 2007, p. 964965; 2016b, p. 144; 2019, p. 150; please refer to Dębowski, 2001; Krąpiec, 1976, 2001; Piecuch, 2004; Stępień, 1974; Wolsza, 1999, 2011).

As a rule, experience is defined as 'direct and clear cognition of [...] something individual, given (found) as existing or once existing' (Stępień, 1974 , p. 30; 2001, p. 119). In science, philosophy in particular, the concept of experience is considered the most crucial and the most venerable (Dębowski, 2001, p. 131). It is found in many fields of knowledge, especially in gnoseology, epistemology, and methodology. It is used in all serious systems of philosophy, and the attempts to specify its value have repeatedly been accompanied by a reverse process leading to the emergence of contradictory opinions.

The existence of the epistemological and methodological perspective in experience related considerations is due to the fact that it is 'equivalent to any kind of cognition and any kind of action' (ibidem, p. 133), relating to various forms of activity and its result: knowledge, skills and abilities. The epistemological theory is related to cognition, whereas the methodological perspective is related to a specific action, with the former preceding and de-

Dr Leszek Waga - Chair of Pastoral Theology, Catechetics, Pedagogy and Psychology, Institute of Theology, University of Opole; address for correspondence: ul. Drzymały 1A, 45-342 Opole; e-mail: lwaga@uni.opole.pl; ORCID: https://orcid.org/0000-0002-2159-5950. 
termining the latter, and both deriving from the ontological perspective. Moreover, in detailed sciences, experience has multiple meanings, often arising from the spreading linguistic trend and manner (Wolsza, 2011, p. 11).

The purpose of this article is to outline the application of the concept of experience in the pedagogical reflection on family and to highlight the need for a multidimensional and integrated understanding of the concept, i.e. an understanding presenting a possibly most extensive educational potential of experience itself while avoiding any reductionism.

These analyses will begin with a presentation of the ways of understanding experience in the pedagogical reflection on family and a demonstration of the role of experience acquired within the family as the basis for the formation of further experiences. Further on, the article will discuss the relationship between sensory experiences and experiences in the context of family life. This will be followed by an analysis of a special kind of experience-experiencing the value of oneself and its references to the development of the child within the family. Finally, the last section will discuss the subjective aspect of the child's experience within the family, i.e. the importance of the family environment as a place of the formation and acquisition of experience.

The considerations presented are based on the author's own studies regarding the role of experience in the formation of pedagogical knowledge (Waga, 2016a; 2019). In addition, matters regarding family matters have been elaborated on.

\section{THE WAYS OF UNDERSTANDING EXPERIENCE IN THE PEDAGOGICAL REFLECTION ON FAMILY}

There are numerous classifications and typologies of understanding the concept of experience. Below you will find the main ones used in the pedagogical literature related to family matters.

A well-known typology of experience in philosophy lists the empirical concept (requiring the participation of sensory phenomena) as well as the phenomenological and hermeneutic concepts (overcoming the earlier empirical model). In analyses covering the subject matter of experience, phenomenology and hermeneutics not only recognised sensory data and any one-off and actual states of things but also allowed for any direct data, i.e. permanent states of things and perfect states. Thus, those concepts expanded the 
concept of experience with acts of observing and experiencing (Wolsza, 1999; Waga, 2016b, 2019; please refer to Stępień, 1974, 2001), although it should be noted that the adoption of the phenomenological understanding of experience is sometimes contested (please refer to Woleński, 2007, p. 419).

Another philosophical typology refers to the analyses carried out by Kazimierz Twardowski (1866-1938) who claimed that experience was either an act of cognition or its product, i.e. its result, defined information or knowledge (Twardowski, 1997, p. 118; please refer to Kamiński, 1992, p. 13).

The above two philosophical typologies of experience can be used in pedagogy, especially in the analysis of its structural and functional aspects.

Structural aspects are closely related to the very objective and subjective elements of the educational relationship structure that are either objective (pupils and tutors) or subjective (educational situation) aspects of a particular experience. On the other hand, allowing for the functional aspect leads to three types of experience-action: repetition, participation and reproduction (Znaniecki, 2009, p. 84-85; please refer to Jankowska, 2001, p. 187-188).

Experience understood as the repetition of an action occurs when the actions of the tutor and pupil are formally the same but functionally different. The tutor performs an action to instruct the pupil, and the pupil undertakes the action to gain an ability (Znaniecki, 2009, p. 85).

Experience as participation in a pedagogical relationship is an action in which the functions of the tutor and the pupil are identical, but they differ in form. From a formal point of view, each participant in the educational relationship may perform different actions, but because of the clearly defined goals of educational activities, the actions undertaken are attributed the same function (ibidem).

Experience as the reproduction of an action consists in tutors and pupils undertaking actions characterised by the same form and function. F. Znaniecki recognised reproduction in situations in which 'people continually and repeatedly reproduce the same technical formulas while taking part in the same rituals, playing the same songs, reading the same books, teaching students the same geometric patterns. Although their personal goals are different, there is a common objective function that they all fulfil-to use reproduction to preserve a technical formula, a ritual, a piece of music, a book content, or a geometric system' (ibidem, p. 85-86).

All of the above typologies and aspects of experience are applied in many areas of pedagogical knowledge of the family. Of course, along the variations of experience studied in the article, one can also speak of observation 
or experimentation as methodological types of experience in relation to obtaining pedagogical knowledge of the family (Hajduk, 2005, p. 118-121). However, methodological aspects of the instrumentally understood experience will be omitted here since, with some generalisation, it seems that their characteristics in the field of pedagogical knowledge of the family is not specific compared to other areas of pedagogical knowledge.

\section{THE CHILD'S EXPERIENCE WITHIN THE FAMILY AS A BASIS FOR ITS FURTHER DEVELOPMENT}

The role of the child's experience within the family, especially in their thought processes, was particularly emphasised by pragmatism. This belief was one of the impulses to develop a liberal system of education (Kunowski, 2000, p. 110). 'According to pragmatism, experience is the starting point and the destination of any knowledge.' (Melosik, 1995, p. 95). One of the pragmatic pedagogy representatives, John Dewey (1859-1952), seeing the need to develop a theory of experience in pedagogy, highlighted the importance of its continuity and, consequently, the need to develop various interests of the child and to meet their needs. He claimed that children use their opportunities to learn from their own experience which only sometimes is complemented with other people's experience or data deriving from scientific knowledge (Dewey, 1963, p. 25-31; 1967a; Gutek, 2003, p. 88).

The family environment is the first place to experience different kinds of situations. In this context, John Dewey extensively covered experience as a one-off and unique situation having certain intellectual, emotional and volitional content (Dewey, 1975, p. 45-47). This type of experience, considered as an action, is directly related to its result. This indicates a processual approach to education that is well-established in public life. On the other hand, public life formed on the basis of family life and further continued in school life should highlight those actions and repeat them so that the child could gradually learn to know their meaning and play an independent role in them (Dewey, 1967b, p. 7; Dzierzbicka, 1963, p. 302-303).

J. Dewey believed that experience was a combination of an active element and a passive element. In the active sense, it is a test called an experiment. In the passive sense, it is about observing and experiencing. When experiencing something, a person performs a certain action, and then they experience the consequences of the attempt. They perform an action aimed at 
a certain object which subsequently affects the object. It is this characteristic system of interactions in which a person simultaneously performs the active and the passive function that J. Dewey referred to as experience. 'When a child just sticks their finger in the fire, we will not call it an experience. Still, when the child's mind associates that finger movement with the pain they felt as a result of their action, we will say that the event was an experience [...]. The fact itself is but a physical phenomenon [...]. When recognised as a result of some other action, it becomes an experience' (Dewey, 1972, p. 192-193).

On the one hand, J. Dewey emphasised the role of experience acquired by the child in the family environment (at school, these were already treated as experiences-results) but, on the other hand, he also noted the importance of new experiences occurring in the school environment (being a kind of action arising in the process of education). Both forms of experience are linked by the psychological need which consists in maintaining the continuity of the child's development. The said continuity is achieved when the child is enabled to associate gained experiences with new ones (Dewey, 1967b, p. 7).

The importance of past experiences (acquired in family life) in terms of successful schooling was also recognised by Edmund Trempała (1927-2011). He stated that the pupil 'develops in a double circle of educational experiences: compulsory and non-obligatory ones' as 'the practice proves that at present both school and out-of-school environments are the sources of information and experiences' (Trempała, 1993, p. 24, 205). Out-of-school educational experiences can be acquired not only within the family environment but also among peers, friends and the local population, within public organisations, educational institutions, institutions directly popularising culture and art, and through mass communication (ibidem, p. 24, 154, 168-169).

According to E. Trempała, the dependence of children's school achievements on the earlier out-of-school experiences-results had become much more apparent. Earlier experiences form the desired attitudes in young people and motivate their further development (ibidem, p. 21, 29, 64). Therefore, the pedagogue postulated the use of the experiences gained by children and adolescents in the process of parallel education in school activities (ibidem, p. 29, 73, 150-151, 207). The teacher themselves should not only allow for and use those experiences in their work but also prepare their pupils for their further skilful acquisition of experiences in the out-of-school environment (ibidem, p. 42, 198). 


\section{SENSORY OBSERVATIONS AS THE BASIS OF EXPERIENCES}

One of the family pedagogy representatives, Józef Wilk (1937-2003), when undertaking analyses of the first experiences of the child that consisted in the perception of external stimuli from their environment (empirical experiences), noted - in the light of the theory of learning - their impact on the occurrence of experiences (experience in the phenomenological sense, i.e. qualitatively different from empirical experiences). Among the experiences occurring in a young child, he noted the following: 1. experience of parents as experience of God; 2. experience of primal trust; 3. experience of a positive attitude towards life, and 4. pro-social experience (Wilk, 1987, p. 114-139, 201-310; please refer to Braun-Gałkowska, 1997, p. 200).

J. Wilk considered the matter of the emotional development of the child in the light of the conditions of their family environment. It is noteworthy that this approach is not always evidently supported. There are studies relating to the emotional development of the child, and even the role of people important to their development but skipping the category of family as such (please refer to Czajkowska, 2005, p. 208-210).

The relationship between the empirical observations and experiences (not only in the development of the child but also of the parents) is noted before the child is born. Prenatal education focuses on that issue. In this context, Dorota Kornas-Biela wrote about the belief present in the history of humankind regarding the impact of the mental experiences of the mother on the development of the conceived child. These experiences can be positive or unpleasant experiences for the child although their role and nature cannot yet be fully scientifically explained. The so-called prenatal stimulation, consisting in the appropriate stimulation of the nervous system, is applied to evoke those experiences. Through that stimulation, the child can learn to respond to specific stimuli reaching them from the environment. The author presented several forms of such actions. First, the stimulation involves a kind of dialogue carried out by means of messages sent by the body. Moreover, talking to the child, singing to the child, listening to music or hugging the child are postulated. Prenatal feelings result from such stimulation. Thanks to them, the child's brain practices its own abilities and creates new connections between nerve cells, thus enabling the development of important connections of sensory and motor intelligence connections (Kornas-Biela, 2002 , p. $90-111 ; 2005$, p. 17-46; 2009, p. 73-88; please refer to Waga, 2005; 2016b, p. 146-147; Wojaczek, 2011, p. 81-91). 
Prenatal experiences, as D. Kornas-Biela put it, affect the perception of the world in later life, the way of thinking, learning, emotional response, sleep, biorhythm and dominant well-being (Kornas-Biela, 2005, p. 35-36). This statement supports the thesis that there is a close connection between the past experiences-results and the way of experiencing current experiences (as actions).

Specific empirical experiences as actions undertaken in the first period of the child's life are involved in the process of socialisation. This is because the results of those experiences are associated with certain observations and consolidated because of them. In the empirical experiment, thanks to the contact with the world of things, communicating with individual family members and acquiring language skills, the child learns the cultural values that govern the behaviour of the family members (Adamski, 2006, p. 393396; Łuczyński, 2008, p. 35).

The role of the child's experiences built on empirical experiences and influencing the process of socialisation was recognised by André Wery who categorised personal experiences within the family as some of the child's rights. The right is exercised when the parents, adequately to the child's actual abilities, dose their own intervention and accept the child's 'desire for adventure.' They create a space for experience while forming the child's autonomy which characterises the status of an adult and forming an optimal image of the world (Wery, 1988, p. 111-112).

From the pedagogical perspective, the following are desirable: experience of love (Opozda, 2007), experience of security and experience of friendship, with their possible absence being able to lead to the deprivation of the child's needs that takes the form of hospitalism, described in the subject matter literature as the post-alienation syndrome (Łuczyński, 2008, p. 54).

The linking between empirical experiences and observations indicates a relation between experiences-actions and experiences-results noted in, inter alia, issues regarding attitudes. In this context, Maria Grzywak-Kaczyńska (1886-1979) defined love as 'An attitude, i.e. a cognitive-emotional structure developing within the human psyche in the form of preserved traces of different past observations, cognitive and emotional experiences. These preserved traces, i.e. the developing structure, permit that specific experience which we commonly refer to as the feeling of love' (Grzywak-Kaczyńska, 1988, p. 55).

Commenting on this term, Andrzej Łuczyński noted that 'according to the author, one needs to distinguish the experience of feelings [...], i.e. the current 
process, from the constant structure (disposition), i.e. the right attitude. The foregoing distinction between love as a process and love as an attitude is important as it makes us aware of the dependence of different forms of love on the life experience of an individual' (Luczyński, 2008, p. 62).

One might further add that the above differentiation of the values of the concept of love relates to different categories of experience because different ways of understanding love activate different types of experiences, respectively. Love as a process is made up of a series of experiences (i.e. experiences-actions), whereas love as an attitude - as defined by M. Grzywak-Kaczyńska - refers to past experiences, cognitive and emotional experiences (i.e. experience-results making up an individual's specific biography).

\section{EXPERIENCING THE VALUE OF ONESELF WITHIN THE FAMILY}

Experiencing the value of oneself is of particular importance to the child's development. It is important from the perspective of an integral development of the human being. It enables us to discover the truth about ourselves and our nature (Rynio, 1997).

Family may be the primary environment for the formation of the selfesteem experience. Experiencing oneself in the context of the family - as stated by Andrzej W. Janke-is possible in several aspects, in particular: 1. giving rise to a new life being a specific humanistic value, 2. shared responsibility for the development and formation of the child, 3. abandonment of the claim to treat children and adolescents as the property of their parents, 4. building interpersonal relationships within the family based on the acceptance and mutual understanding, 5. remaining ready for mutual and unselfish (but not unlimited) dedication, referring to love, recognising personal dignity and community of value (Janke, 1997, p. 60).

A child might use the observations of the relationships within the family as the basis for the formation of ideas about their own personality and future (M. Tyszkowa, 1985, p. 70-74; Jurga, 1985, p. 145-149). They may also be the source of unwanted and false information, especially when a child consolidates the sense of self-worthlessness when experiencing violence. Children growing up in such conditions find it more difficult to experience their own value in the educational processes (Szabelska, 1997; Grabowiec, 2011). They also find it much more difficult to experience their imperfection because, as noted by A. Łuczyński, they are often excessively punished and 
humiliated because of their mistakes. Depriving them of the right to make their own mistakes makes them underestimate their own value. In adulthood, such experiences often lead to perfectionism or rebellious attitudes ( $\mathrm{Ku}$ czyński, 2008, p. 42-43).

Other negative experiences of children living in dysfunctional families include the experience of spiritual loneliness and the experience of physical rejection. Typically, they occur in situations in which children do not find any emotional support in their parents and they live in an atmosphere of fear (ibidem, p. 40). Such negative situations experienced by a child, caused by their guardians, may lead to experiencing critical events (Krawczyk-Bocian, 2013).

Meanwhile, it is the family that seems to be the environment in which the most significant events take place, preparing young people for future roles. All family members provide experiences and models that influence the attitudes, expectations and beliefs. The lack of certain positive experiences and the excess of negative experiences are sometimes used to explain differences in development that occur between children who are brought up within a family and children from orphanages (Jurga, 1985, p. 157, 196197). 'Children deprived of their natural family and raised at various comprehensive care establishments are most likely to differ significantly in terms of the assessment of their past and their current situation,' wrote Bazyli Baran, adding that 'this results from, among other things, numerous negative experiences acquired even before coming to the establishment as well as during the stay there' (Baran, 1981, p. 27-29; 1985, p. 204). The foregoing opinion evidently highlights the importance of the first experiences of the child to the formation of subsequent experiences in the future.

The above analyses confirm the existence of a link between past experiences-results and current experiences (interpreted as actions). Moreover, experiencing the value of oneself, integrating different forms of experiences (past and present, empirical and phenomenological) fits into a specific process, and the child's living environment plays a crucial role in it.

\section{FAMILY ENVIRONMENT AS A SUBJECTIVE ASPECT OF THE CHILD'S EXPERIENCES}

Experiencing the family environment and the various pedagogical situations in it clearly and directly affects the development of the child (Jarosz, 2015). An individual's living environment is always of an objective and 
subjective nature, that is, the objective environment comprises elements common to all the people living in it, and this environment is perceived and experienced differently in the individual perception of the people involved in it (Wysocka, 2007, p. 21).

Subject matter pedagogy is particularly interested in the problem of the pedagogical situation. It focuses on the material factors of education which in individual environments (family, school, institutional, non-institutional and others) have an impact on the human being that results in the adoption of specific attitudes by the objects of the pedagogical relation (Nowak, 2000, p. $519-565 ; 2008$, p. 311-314). Therefore, the pedagogical situation here is analysed from the perspective of the subjective aspects of the experiences the objects of which are the participants in the pedagogical relation.

The value of the experience of the pedagogical situation is often emphasised by the representatives of phenomenological pedagogy. Krystyna Ablewicz noted that 'the most obvious experience of the pedagogical situation reveals the fact that I'm actually facing two 'subjects' of cognition: 1 . in relation to the human being and 2. in relation to the pedagogical situation [...]. Both the human being and the situation become the subject - the field of pedagogical work' (Ablewicz, 2003, p. 201).

The atmosphere prevailing within the family is one of the many indicators of the pedagogical situation in it (Kunowski, 2000, p. 243-244; Kuźma, 2003 , p. 86). The atmosphere within the family, which is also referred to as the home atmosphere, or the family climate, is assessed depending on the degree of: respect for work, selfless sacrifice, joy and serenity (Jeleńska, 1930 , p. 45-57; Kunowski, 2000, p. 244). Its quality depends on the material conditions of the family and the standard of their life as well as on the culture prevailing in it. It grows out of the natural bonds between its individual members. Emotional saturation is a unique feature of the family climate. Depending on the quality of this saturation, the following family climate types are usually distinguished: democratic, autocratic and chaotic family atmosphere (Wilk, 2002, p. 52-56). The home atmosphere, being an indicator of the pedagogical situation, is a factor that determines and explains the individual experiences-observations of human beings.

Referring to older concepts of education, one may note that the organisation of the pedagogical environment being a place of formation of new experiences was the main postulate of education in the concept developed by Anton Siemionowicz Makarenko (1888-1939). Putting a particular emphasis on the dynamic aspect of education, he influenced his pupils using a continually 
changing system of interrelations and organisational forms. Work and the ability to manage were the main dynamising factors. According to A. Makarenko, interaction through the pedagogical environment was supposed to provide pupils with a basis for the creation of a new moral experience which would become the foundation of their behaviour and attitude towards life (Lewin, 1977, p. 371-372; Chmaj, 1960, p. 177-187). Analysing the process of organisation of school education, the pedagogue put forward postulates on education in the family. He signalled the need to 'organise the child's experiences from the earliest years of her or his life' (Makarenko, 1956, p. 340).

A. Makarenko's opinion is to a large extent in line with the postulates of J. Dewey who perceived school experiences as a kind of continuation of the experiences gained within the family environment.

In the context of experience, one might also refer to yet another older concept of education developed by Stanisław Teofilewicz Szacki (18781934). The author, referring to the views of J. Dewey and, at the same time, to the postulates of the school of work, stressed the exceptional importance of the pupil's experience in school education. He postulated that tutors discover, analyse and generalise their pupils' experiences, and that they identify new experiences which would correspond to the observations made by children. Then, tutors would compare the new school experiences with the experiences gained at home. According to S. Szacki, the relationship between the experiences gained at home and the experience gained at school had to be reversible as experiences gained by children in the school environment should then be transferred in the form of habits to the family environment (Łubniewski, 1972, p. XXXIII).

The reversible nature of experiences gained in both of those two environments would then make it possible to consider them in the context of the division of experiences into: repetition, participation and reproduction by proposed F. Znaniecki. This, in turn, would make it possible to analyse the process of becoming a human being in the context of pre-figurative, post-figurative and co-figurative systems functioning within the family (please refer to Jarosz, 2015).

\section{CONCLUSION}

The foregoing analyses covering the problem of experience in the field of pedagogical reflection on the family have shown a plurality of contexts in 
which the concept of experience is used. At the same time, they made it possible to recognise the close links between different types of experience (actions-results, empirical concepts-phenomenological concepts). They also showed some structural links between the experiences of parents as tutors and the experiences of children as pupils. The reflections presented lead to the conclusion that the problem of the experiences of the child within the family should be discussed so as to allow for both the objective components of the pedagogical relationship and its subjective aspect, i.e. the pedagogical environment as the place of formation and acquisition of experiences.

\section{REFERENCES}

Ablewicz, K. (2003). Teoretyczne i metodologiczne podstawy pedagogiki antropologicznej. Studium sytuacji wychowawczej. Kraków: Wydawnictwo Uniwersytetu Jagiellońskiego.

AdAmski, F. (2006). Rodzinna socjalizacja. In: T. PILCH (ed.), Encyklopedia pedagogiczna XXI wieku (vol. 5, p. 393-396). Warszawa: Wydawnictwo Akademickie „Żak”.

BARAN, B. (1981). Rola więzi spoleczno-emocjonalnej w ksztattowaniu osobowości dziecka (Studium porównawcze osobowości dzieci wychowywanych w państwowych domach dziecka $i$ w rodzinach). Warszawa-Poznań: Wyższa Szkoła Pedagogiczna w Szczecinie, Państwowe Wydawnictwo Naukowe.

BARAN, B. (1985). Wyobrażenia o własnej przeszłości dzieci wychowywanych poza rodziną. W: M. Tyszkowa (ed.), Rozwój dziecka w rodzinie i poza rodzina (p. 203-227). Poznań: Wydawnictwo Naukowe Uniwersytetu im. Adama Mickiewicza w Poznaniu.

Braun-GaŁkOwSKA, M. (1997). Rodzina jako wartość. Ateneum Kaptańskie, 2-3(531-532), 200-208.

Chmaj, L. (1960). Antoni Makarenko. Warszawa: „Książka i Wiedza”.

Czajkowska, A. (2005). Procesy emocjonalne. In: W. Pilecka, G. RudKowsKa, L. Wrona (eds.), Podstawy psychologii. Podręcznik dla studentów kierunków nauczycielskich (p. 197211). Kraków: Wydawnictwo Naukowe Akademii Pedagogicznej.

Dewey, J. (1963). Education and Experience. New York: Macmillan Publishing Company.

DEweY, J. (1967a). Zainteresowanie i wysiłek w związku z wychowaniem woli. In: IDEM, Wybór pism pedagogicznych (p. 17-53). Wrocław-Warszawa-Kraków: Zakład Narodowy im. Ossolińskich-Wydawnictwo Polskiej Akademii Nauk.

DEWEY, J. (1967b). Moje pedagogiczne credo. In: IDEM, Wybór pism pedagogicznych (p. 3-16). Wrocław-Warszawa-Kraków: Zakład Narodowy im. Ossolińskich-Wydawnictwo Polskiej Akademii Nauk.

DEWey, J. (1972). Demokracja i wychowanie. Wprowadzenie do filozofii wychowania. WrocławWarszawa-Kraków-Gdańsk: Zakład Narodowy im. Ossolińskich-Wydawnictwo Polskiej Akademii Nauk.

Dewey, J. (1975). Sztuka jako doświadczenie. Wrocław-Warszawa-Kraków-Gdańsk: Zakład Narodowy im. Ossolińskich, Wydawnictwo Polskiej Akademii Nauk. 
DęBowski, J. (2001). Świadomość. Poznanie. Naoczność poznania. Lublin: Wydawnictwo Uniwersytetu Marii Curie-Skłodowskiej.

DzierzBicka, W. (1963). Metoda projektów. In: W. DzierzBicka, S. Dobrowolski (eds.), Eksperymenty pedagogiczne $w$ Polsce $w$ latach 1900 - 1939 (p. 302-334). Wrocław-WarszawaKraków: Zakład Narodowy im. Ossolińskich-Wydawnictwo Polskiej Akademii Nauk.

GrabowIEC, A. (2011). Samoocena dzieci krzywdzonych w rodzinie. Lublin: Wydawnictwo Uniwersytetu Marii Curie-Skłodowskiej.

GrZYWAK-KACZYŃSKA, M. (2008). Trud rozwoju. Warszawa: Instytut Wydawniczy Pax.

Gutek, G.L. (2003). Filozoficzne i ideologiczne podstawy edukacji. Gdańsk: Gdańskie Wydawnictwo Psychologiczne.

HAJDUK, Z. (2005). Ogólna metodologia nauk. Lublin: Wydawnictwo KUL.

JANKE, A.W. (1997). Rodzina jako przestrzeń doświadczania wartości samego siebie. In: A.M. TCHORZEWSKI (ed.), Doświadczanie wartości samego siebie w procesach edukacyjnych (p. 54-62). Bydgoszcz: Wydawnictwo Uczelniane WSP w Bydgoszczy.

JANKOwSKA, D. (2001). Teoria wiedzy i nauki Floriana Znanieckiego - w świetle współczesnych dyskusji nad możliwościami naukowego poznania. In: A. BoGAJ (ed.), Rozwój pedagogiki ogólnej. Inspiracje i ograniczenia kulturowe oraz poznawcze (p. 182-190). WarszawaKielce: Akademia Świętokrzyska im. J. Kochanowskiego w Kielcach-Wydawnictwo Instytutu Badań Edukacyjnych w Warszawie.

JARosz, K. (2015). Miejsce międzypokoleniowego uczenia się w procesie hominizacji. Rocznik Andragogiczny, 22, 163-180.

JeleŃSKA, L. (1930). Sztuka wychowania. Warszawa: „Nasza Księgarnia”, Spółka Akc. Związku Polskiego Nauczycielstwa Szkół Powszechnych.

Jurga, M. (1985). Doświadczenie społeczne i rozwój osobowości wychowanek domów dziecka. In: M. Tyszkowa (ed.), Rozwój dziecka w rodzinie i poza rodzina (p. 153-202). Poznań: Wydawnictwo Naukowe Uniwersytetu im. Adama Mickiewicza w Poznaniu.

KAMIŃSKI, S. (1992). Nauka i metoda. Pojęcie nauki i klasyfikacja nauk. Lublin: Towarzystwo Naukowe KUL.

KoRnAs-Biela, D. (2002). Wokót początku życia ludzkiego. Warszawa: Instytut Wydawniczy Pax.

Kornas-Biela, D. (2005). Okres prenatalny. In: B. Harwas-Napierala, J. Trempala (eds.), Psychologia rozwoju człowieka, t. 2, Charakterystyka okresów życia człowieka (p. 17-46). Warszawa: Wydawnictwo Naukowe PWN.

Kornas-Biela, D. (2009). Pedagogika prenatalna. Nowy obszar nauk o wychowaniu. Lublin: Wydawnictwo KUL.

KrawCZyK-Bocian, A. (2013). Doświadczanie zdarzeń krytycznych. Narracje biograficzne Dorostych Dzieci Alkoholików. Bydgoszcz: Wydawnictwo Uniwersytetu Kazimierza Wielkiego.

KrąPIEC, M.A. (1976). Doświadczenie i metafizyka. Roczniki Filozoficzne, 1, 5-16.

Krąpiec, M.A. (2001). Doświadczenie. In: A. Maryniarczyk (ed.), Powszechna Encyklopedia Filozofii, vol. 2 (p. 673-676). Lublin: Polskie Towarzystwo Tomasza z Akwinu.

Kunowski, S. (2000). Podstawy wspótczesnej pedagogiki. Warszawa: Wydawnictwo Salezjańskie.

KuźmA, J. (2003). Prawa i dobro dziecka - deklaracje i rzeczywistość. In: J. WILK (ed.), W stużbie dziecku, vol. 1: Stulecie dziecka - blaski i cienie (p. 73-86). Lublin: Katedra Pedagogiki Rodziny KUL. 
LewIN, A. (1977). Zasady wychowawcze Makarenki. In: W. OKoŃ (ed.), Szkoty eksperymentalne w świecie 1900 - 1975 (p. 365-383). Warszawa: Wydawnictwa Szkolne i Pedagogiczne.

Łubniewski, W. (1972). Wstęp. In: S. SzAcki, Pisma pedagogiczne (p. V-LXVIII). WrocławWarszawa-Kraków-Gdańsk: Zakład Narodowy im. Ossolińskich-Wydawnictwo Polskiej Akademii Nauk.

ŁUCZYŃSKI, A. (2008). Dzieci $w$ rodzinach zastepczych i dysfunkcjonalnych. Lublin: Wydawnictwo KUL.

MakarenKo, A. (1956). Książka dla rodziców. Warszawa: Państwowe Zakłady Wydawnictw Szkolnych.

MelosiK, Z. (1995). Pragmatyzm i edukacja w Stanach Zjednoczonych: między poglądami J. Deweya a współczesną rzeczywistością. In: J. RUTKOwIAK (ed.), Odmiany myślenia o edukacji (p. 93-117). Kraków: Oficyna Wydawnicza „Impuls”.

NowaK, M. (2000). Podstawy pedagogiki otwartej. Ujęcie dynamiczne w inspiracji chrześcijańskiej. Lublin: Redakcja Wydawnictw KUL.

NowaK, M. (2008). Teorie i koncepcje wychowania. Warszawa: Wydawnictwa Akademickie i Profesjonalne.

OPOZDA, D. (2007). Doświadczenie miłości w relacji wychowawczej siłą rozwoju rodzica i dziecka. In: A. RYNIO (ed.), Wychowanie chrześcijańskie między tradycja a wspótczesnościa (p. 471-479). Lublin: Wydawnictwo KUL.

Piecuch, J. (2004). Doświadczenie Boga. Propozycja Bernharda Weltego na tle sporu o pojęcie doświadczenia fenomenologicznego. Opole: Redakcja Wydawnictw Wydziału Teologicznego Uniwersytetu Opolskiego.

RYNIO, A. (1997). Doświadczanie wartości własnej osoby drogą rozwoju religijnego. In: A.M. TCHORZEWSKI (ed.), Doświadczanie wartości samego siebie w procesach edukacyjnych (p. 79-83). Bydgoszcz: Wydawnictwo Uczelniane WSP w Bydgoszczy.

STĘPIEŃ, A.B. (1974). Rola doświadczenia w punkcie wyjścia metafizyki. Zeszyty Naukowe KUL, $4,29-37$

StĘPIEŃ, A.B. (2001). Wstęp do filozofii. Lublin: Towarzystwo Naukowe KUL.

SzABELSKA, G. (1997). Doświadczanie przemocy jako przeszkoda w przeżywaniu pozytywnej wartości samego siebie. In: A. M. TCHORZEWSKI (ed.), Doświadczanie wartości samego siebie w procesach edukacyjnych (p. 145-149). Bydgoszcz: Wydawnictwo Uczelniane WSP w Bydgoszczy.

TrempaŁa, E. (1993). Szkoła a edukacja równoległa (nieszkolna). Poglądy, doświadczenia, propozycje. Bydgoszcz: Wydawnictwo Uczelniane Wyższej Szkoły Pedagogicznej w Bydgoszczy.

TwARDOWSKI, K. (1997). O czynnościach i wytworach. Kilka uwag z pogranicza psychologii, gramatyki i logiki. In: T. RZEPA (ed.), Psychologia w szkole lwowsko-warszawskiej. Twardowski. Witwicki. Baley. Błachowski. Kreutz. Lewicki. Tomaszewski (p. 109-141). Warszawa: Wydawnictwo Naukowe PWN.

TYsZKowA, M. (1985). Rola rodziny w kształtowaniu się wyobrażeń o własnej przyszłości i aspiracji życiowych dzieci i młodzieży. In: EADEM (ed.), Rozwój dziecka w rodzinie i poza rodziną (p. 69-100). Poznań: Wydawnictwo Nauko-we Uniwersytetu im. Adama Mickiewicza w Poznaniu.

Waga, L. (2005). Znaczenie kontaktu dotykowego dla rozwoju sfery emocjonalnej dziecka. Lublin: mps KUL. 
WAGA, L. (2007). Znaczenie doświadczenia w wychowaniu religijnym w ujęciu Luigiego Giussaniego. In: A. RYNIO (ed.), Wychowanie chrześcijańskie między tradycja a współczesnościa (p. 963-975). Lublin: Wydawnictwo KUL.

WAGA, L. (2016a). Rola doświadczenia w tworzeniu wiedzy pedagogicznej. Lublin: mps KUL.

WAGA, L. (2016b). Wychowawczy potencjał doświadczenia bliskości między rodzicami i dziećmi w wybranych oddziaływaniach rodzicielskich. In: R. CHAŁUPNIAK, T. MicHALEWSKI, E.K. SMAK (eds.), Wychowanie w rodzinie: od bezradności ku możliwościom (p. 143-153). Opole: Redakcja Wydawnictw Wydziału Teologicznego UO.

Waga, L. (2019). Typologies of the Understanding of the Experience Notion in Pedagogy. Przegląd Badań Edukacyjnych, 28(1), 149-160. http://dx.doi.org/10.12775/PBE.2019.008.

Wery, A. (1988). Wychowanie w rodzinie. In: M. Debesse, G. Mialaret (eds.), Rozprawy o wychowaniu, t. 1: Filozoficzne, psychologiczne i socjologiczne aspekty wychowania (p. 107137). Warszawa: Państwowe Wydawnictwo Naukowe.

WiLK, J. (1987). Znaczenie pierwszych doświadczeń dla religijnego wychowania małego dziecka w rodzinie. Lublin: Redakcja Wydawnictw KUL.

WILK, J. (2002). Pedagogika rodziny. Zagadnienia wybrane. Lublin: Instytut Pedagogiki Katolickiego Uniwersytetu Lubelskiego, Wydawnictwo Poligrafia Salezjańska.

WoJACZeK, M. (2011). Rozwój więzi z dzieckiem w prenatalnym okresie życia. In: E. LichteNBERG-KoKoszKa, E. JANIUK, J. DZIERŻANOwSKi (eds.), Ciąża czy stan błogosławiony? Zagadnienia interdyscyplinarne (p. 81-91). Kraków: Oficyna Wydawnicza „Impuls”.

Woleński, J. (2007). Epistemologia. Poznanie. Prawda. Wiedza. Realizm. Warszawa: Wydawnictwo Naukowe PWN.

Wolsza, K. (1999). Rola doświadczenia transcendentalnego w poznaniu filozoficznym. Opole: Wydział Teologiczny Uniwersytetu Opolskiego.

Wolsza, K. (2011). Zarys teorii podstawowego doświadczenia filozoficznego. In: IDEM, Religijne wymiary doświadczenia i myślenia (p. 11-27). Opole: Wydawnictwo i Drukarnia Świętego Krzyża w Opolu.

WysockA, E. (2007). Człowiek a środowisko życia. Podstawy teoretyczno-metodologiczne diagnozy. Warszawa: Wydawnictwo Akademickie „Żak”.

ZNANIECKI, F. (2009). Metoda socjologii. Warszawa: Wydawnictwo Naukowe PWN.

\section{EXPERIENCE IN THE PEDAGOGICAL REFLECTION ON FAMILY}

\section{SUMMARY}

The purpose of this article is to outline the application of the concept of experience in the pedagogical reflection on the family, and to indicate the need for a multidimensional and integrated understanding of this concept.

The article first presents the ways of understanding the concept of experience in the pedagogical reflection on the family. Then, it presents the role of the experiences acquired within the family as the basis for the formation of further experiences by children. Further on, the article discusses the relationship between sensory experiences and experiences in the context of family life. This is followed by an analysis of a special kind of experience-experiencing the value of oneself and its references to the development of the child within the family. The last section 
discusses the role of the subjective aspect of the child's experiences within the family, i.e. the importance of the family environment as a place of the formation and acquisition of experiences.

Keywords: family pedagogy; experience; pragmatism; family atmosphere; self-esteem.

\section{DOŚWIADCZENIE W PEDAGOGICZNEJ REFLEKSJI NAD RODZINĄ}

\section{STRESZCZENIE}

Celem niniejszego artykułu jest przedstawienie krótkiego zarysu stosowania pojęcia „doświadczenie" w pedagogicznej refleksji nad rodziną oraz wskazanie na potrzebę wielowątkowego $\mathrm{i}$ integralnego rozumienia tego pojęcia.

Najpierw zaprezentowane są sposoby rozumienia pojęcia „doświadczenie” w pedagogicznej refleksji nad rodziną. Potem ukazana jest rola nabywanego w rodzinie doświadczenia jako bazy do kształtowania dalszych doświadczeń przez dzieci. Później omawiany jest związek istniejący między doświadczeniami odbieranymi przez zmysły a przeżyciami w kontekście życia rodzinnego. W dalszej kolejności przeanalizowany jest szczególny rodzaj doświadczenia - przeżycie wartości samego siebie z jego odniesieniami do rozwoju dziecka w rodzinie. W ostatnim punkcie jest omówiona rola przedmiotowej strony doświadczeń dziecka w rodzinie, czyli znaczenie środowiska rodzinnego jako miejsca powstawania i nabywania doświadczeń.

Słowa kluczowe: pedagogika rodziny; doświadczenie; pragmatyzm; atmosfera rodziny; samoocena. 